Jurnal Kependudukan Indonesia | Vol. 10 No. 2 Desember 2015 | 139-150

JURNAL KEPENDUDUKAN INDONESIA

p-ISSN : 1907-2902 (Print)

e-ISSN : 2502-8537 (Online)

\title{
PENCIPTAAN MATA PENCAHARIAN ALTERNATIF: STRATEGI PENGURANGAN KEMISKINAN DAN PERLINDUNGAN SUMBER DAYA LAUT (STUDI KASUS KOTA BATAM DAN KABUPATEN PANGKAJENE DAN KEPULAUAN)
}

\section{ALTERNATIVE INCOME GENERATING ACTIVITIES: A STRATEGY FOR POVERTY ALLEVIATION AND MARINE RESOURCES PROTECTION (CASE STUDY FROM THE CITY OF BATAM AND PANGKAJENE DAN KEPULAUAN DISTRICT)}

\author{
Mita Noveria* dan Meirina Ayumi Malamassam** \\ Pusat Penelitian Kependudukan, Lembaga Ilmu Pengetahuan Indonesia \\ Korespodensi Penulis: *) mita_noveria@yahoo.com**) ayumi.malamassam @gmail.com
}

\begin{abstract}
One attempt to alleviate poverty of fishermen is, among others, by creating alternative income generating activities to facilitate additional income. The activities are implemented through diversification of household income's sources. This enables fishermen to carry out jobs other than fisheries, which is also an effective effort to conserve marine resources. The reason is because alternative income generating activities could reduce the high dependency of fishery households on marine resources. This paper aims to assess alternative income-generating activities implemented through the Coral Reef Rehabilitation and Management Program (Coremap). It is based on two Coremap study sites, ie. the City of Batam in the Province of Riau Islands and the district of Pangkajene Islands (Pangkep) in the Province of South Sulawesi. This paper based on qualitative data, particularly on the supporting and challenging factors in implementing income-generating activities. The result of data analysis shows that the alternative income generated activities offered by the program tend to neglect the work habits of the targeted groups. For example, the activities requested target population to work collectively in a group. However, in reality, they are not accustomed to such manner. Moreover, the initiated income generated activities took quite long time to harvest, while the target population normally carried out quick yielding jobs.
\end{abstract}

Keywords: Poverty Alleviation, Income-Generating Activities, The City of Batam, The District of Pangkajene Islands

\begin{abstract}
Abstrak
Salah satu cara untuk mengurangi kemiskinan di kalangan nelayan adalah menciptakan kegiatan ekonomi alternatif yang dapat menghasilkan pendapatan tambahan. Kegiatan ini antara lain diwujudkan melalui diversifikasi sumber pendapatan rumah tangga. Ini memungkinkan para nelayan melakukan pekerjaan-pekerjaan di luar bidang perikanan tangkap, sekaligus merupakan suatu upaya untuk memelihara kelestarian sumber daya laut. Mata pencaharian alternatif dapat mengurangi ketergantungan yang tinggi terhadap sumber daya laut dan pesisir. Tulisan ini bertujuan untuk mengkaji upaya penciptaan mata pencaharian alternatif yang dilakukan melalui program rehabilitasi dan pengelolaan terumbu karang (Coral Reef Rehabilitation and Management Program - Coremap). Data yang digunakan adalah data kualitatif, bersumber dari penelitian di dua lokasi, yaitu Kota Batam (Kepulauan Riau) dan Kabupaten Pangkajene dan Kepulauan (Pangkep) di Sulawesi Selatan. Hasil analisis data memperlihatkan bahwa upaya penciptaan alternatif pekerjaan cenderung kurang mempertimbangkan kondisi/kebiasaan kerja yang selama ini dilaksanakan oleh kelompok target. Sebagai contoh, pekerjaan alternatif yang ditawarkan dalam COREMAP dilakukan secara berkelompok, namun sayangnya bekerja dalam kelompok belum menjadi kebiasaan penduduk setempat. Selain itu, pekerjaan alternatif yang ditawarkan dalam program ini umumnya memerlukan waktu yang relatif lama untuk memperoleh hasilnya, padahal penduduk masih terbiasa memperoleh penghasilan dengan cara cepat.
\end{abstract}

Kata Kunci: Pengurangan Kemiskinan, Mata Pencaharian Alternatif, Kota Batam, Kabupaten Pangkajene dan Kepulauan 


\section{PENDAHULUAN}

Kemiskinan masih menjadi persoalan yang serius di negara-negara berkembang, termasuk Indonesia. Hal ini terbukti dengan dimasukkannya isu kemiskinan sebagai salah satu target Millenium Development Goals (MDGs) ${ }^{1}$, khususnya penurunan jumlah penduduk miskin. Jika mengacu pada target MDGs, pemerintah harus menurunkan proporsi penduduk miskin dari 15,10 persen pada tahun $1990^{2}$ (www.bps.go.id) menjadi 7,55 persen pada tahun 2015. Berdasarkan data yang menunjukkan bahwa sampai bulan Maret 2013 proporsi penduduk miskin Indonesia adalah 11,37 persen $^{3}$, maka upaya yang lebih keras perlu dilakukan untuk mencapai sebagian target dari tujuan pertama MDGs tersebut.

Pasca kesepakatan MDGs tahun 2015, isu kemiskinan masih mendapat perhatian dalam pembangunan, khususnya di negara-negara berkembang. Hal ini terbukti dengan dicantumkannya kemiskinan sebagai salah satu tujuan Sustainable Development Goals (SDGs), yaitu tujuan 1: "menghentikan segala bentuk kemiskinan di setiap tempat - end poverty in all its forms everywhere" (United Nations, 2015). Kenyataan tersebut memperlihatkan seriusnya pemerintah berbagai negara di dunia dalam menangani persoalan kemiskinan, kemungkinan karena dapat menimbulkan berbagai implikasi negatif terhadap penduduk.

Upaya-upaya untuk mengurangi jumlah penduduk miskin sesungguhnya telah dilakukan oleh berbagai pihak, baik pemerintah maupun lembaga-lembaga nonpemerintah. Beberapa program sepenuhnya dilaksanakan oleh pemerintah, dalam arti pemerintah menyediakan dana dan pendampingan teknis, sedangkan yang lainnya dilakukan dengan bantuan dari pihak-pihak selain pemerintah. Salah satu contoh program penanggulangan kemiskinan adalah IDT

\footnotetext{
${ }^{1}$ MDGs adalah kesepakatan yang ditandatangani oleh 189 kepala negara anggota Perserikatan Bangsa-Bangsa (PBB), termasuk Indonesia, pada tahun 2000. MDGs mencantumkan 8 tujuan yang hendak dicapai oleh negara-negara penandatangan sampai dengan tahun 2015 (http://www.undp.org). Penanggulangan kemiskinan merupakan tujuan pertama, yang secara lengkap dicantumkan "menanggulangi kemiskinan dan kelaparan". Secara spesifik target yang hendak dicapai berkaitan dengan penanggulangan kemiskinan adalah menurunkan persentase penduduk yang berpendapatan kurang dari 1 dolar sehari sebanyak 50 persen selama tahun 1990-2015.

${ }^{2}$ Garis kemiskinan untuk daerah perkotaan adalah Rp. 20.614,/kapita/bulan, sedangkan untuk daerah perdesaan sebesar Rp. 13.295,-/kapita/bulan.

${ }^{3}$ Pada bulan Maret 2013 garis kemiskinan untuk daerah perkotaan adalah Rp. 289.014,-/kapita/bulan dan untuk daerah perdesaan sebesar Rp. 253.273,-/kapita/bulan. Dengan tukar 1 dolar AS = Rp. 10.000,-, jumlah tersebut kurang dari 1 dolar per hari.
}

(Inpres Desa Tertinggal) yang dilaksanakan pada masa Orde Baru berdasarkan Instruksi Presiden Nomor 5 Tahun 1993 tentang Peningkatan Penanggulan Kemiskinan. Setelah itu, juga diselenggarakan Program Pengembangan Kecamatan (PPK) pada tahun 1998 dan Program Penanggulangan Kemiskinan di Perkotaan (P2KP) di tahun 1999 (http://www.pnpmperdesaan.or.id). Dua program terakhir dilaksanakan oleh institusi pemerintah yang berbeda, yaitu PPK oleh Departemen Dalam Negeri dan P2KP oleh Departemen Pekerjaan Umum. Beberapa kementerian/lembaga teknis lainnya juga melaksanakan program penanggulangan kemiskinan, seperti KUBE (Kelompok Usaha Bersama) oleh Departemen Sosial dan Pemberdayaan Ekonomi Masyarakat Pesisir (PEMP) oleh Departemen Kelautan dan Perikanan. Pada tahun 2007 pemerintah meluncurkan Program Nasional Pemberdayaan Masyarakat (PNPM) Mandiri, yang tidak hanya untuk mengurangi kemiskinan tetapi juga bertujuan untuk memberdayakan masyarakat.

Semua program penanggulangan kemiskinan memiliki berbagai kegiatan yang secara langsung maupun tidak langsung berkaitan dengan peningkatan pendapatan masyarakat targetnya. Kegiatan yang bersifat langsung adalah pemberian bantuan untuk usaha ekonomi produktif berupa (tambahan) modal usaha dan pendampingan teknis dalam pelaksanaan kegiatan, serta bantuan untuk memasarkan produk-produk yang dihasilkan masyarakat penerima bantuan. Sementara itu, kegiatan yang tidak langsung antara lain pembangunan infrastruktur jalan dan jembatan untuk menghilangkan keterisolasian daerah (http://www.pnpm-perdesaan.or.id). Hal ini bertujuan untuk memudahkan akses masyarakat dalam melakukan kegiatan ekonomi produktif, yang pada gilirannya berkontribusi terhadap peningkatan pendapatan masyarakat. Dengan upaya yang komprehensif tersebut, diharapkan terjadi peningkatan kondisi ekonomi masyarakat.

Program untuk mengurangi penduduk miskin juga dilaksanakan dengan target khusus, yaitu penduduk miskin perempuan yang tinggal di perdesaan. Program tersebut diselenggarakan oleh pemerintah, melalui Badan Koordinasi Keluarga Berencana Nasional (BKKBN), dikenal dengan Usaha Peningkatan Pendapatan Keluarga Sejahtera (UPPKS). Melalui UPPKS, perempuan yang menjadi kelompok target bisa memperoleh pinjaman uang untuk kegiatan ekonomi produktif, dengan catatan mereka harus memiliki tabungan di bank, yang dikenal dengan Takesra (Tabungan Keluarga Sejahtera) (Prihatinah, dkk. 2001). Meskipun target program adalah 
perempuan, tujuan yang hendak dicapai adalah peningkatan ekonomi rumah tangga.

Departemen Kelautan dan Perikanan bekerja sama dengan beberapa lembaga donor internasional seperti World Bank (WB) dan Asian Development Bank (ADB) meluncurkan Coremap ${ }^{4}$ (Coral Reef Rehabilition and Management Program) yang dilaksanakan di wilayah pesisir dan kepulauan di 10 provinsi. Dua di antara 10 provinsi yang terpilih sebagai lokasi program tersebut adalah Kepulauan Riau dan Sulawesi Selatan. Coremap memiliki beberapa kegiatan, yang secara langsung maupun tidak langsung berkaitan dengan pelestarian terumbu karang, khususnya dan sumber daya laut pada umumnya, serta peningkatan kondisi ekonomi masyarakat. Kegiatan yang terakhir ini secara implisit memperlihatkan bahwa Coremap terkait dengan upaya penurunan kemiskinan. Dalam dokumen Coremap dicantumkan bahwa program ini bertujuan untuk meningkatkan pendapatan masyarakat di lokasi implementasinya sebesar 2 persen per tahun dan pada akhir program sebanyak 10.000 rumah tangga mengalami peningkatan taraf hidup (Project Appraisal Document, 2005). Salah satu kegiatan program tersebut adalah penciptaan mata pencaharian alternatif (MPA) yang bertujuan untuk meningkatkan pendapatan masyarakat di lokasi program. Dalam kondisi sumber daya laut yang makin berkurang hasilnya, yang berakibat pada menurunnya penghasilan masyarakat, penciptaan MPA menjadi salah satu strategi untuk mencegah bertambahnya penduduk miskin di lokasi program dan bahkan untuk meningkatkan penghasilan mereka. Selain itu, melalui penciptaan MPA diharapkan ketergantungan ekonomi masyarakat pesisir dan kepulauan yang tinggi terhadap sumber daya laut dapat dikurangi, agar kondisi sumber daya alam tersebut terjaga kelestariannya.

Namun sayangnya, program-program yang telah dilaksanakan cenderung kurang mempertimbangkan kondisi sosial budaya, termasuk kebiasaan masyarakat di lokasi program dalam melaksanakan aktifitas ekonomi. Sebagai contoh, kebanyakan kegiatan dilakukan secara berkelompok, padahal cara kerja berkelompok bukan kebiasaan dan bahkan tidak pernah dipraktekkan oleh mereka yang menjadi kelompok target. Akibatnya, tidak semua penerima bantuan ekonomi produktif terlibat kegiatan yang dilaksanakan kelompok. Dalam kasus dana bergulir, kurang terlibatnya semua anggota kelompok

\footnotetext{
${ }^{4}$ Program ini diluncurkan dengan pertimbangan rusaknya terumbu karang di berbagai daerah, antara lain akibat eksploitasi berlebihan terhadap sumber daya laut tanpa mempertimbangkan kelestariannya.
}

berpengaruh negatif terhadap kelangsungan kegiatan karena dana yang telah diberikan kepada masyarakat sebagai modal usaha tidak berkembang. Hal ini tidak sejalan dengan indikator keberhasilan program, misalnya IDT yang menyatakan bahwa berkembangnya usaha produktif anggota dan kelompok serta makin kuatnya permodalan kelompok merupakan salah satu di antaranya (Bappenas, 1994: 18)

Tulisan ini bertujuan untuk mengkaji upaya penanggulangan kemiskinan yang telah dilaksanakan oleh Coremap di dua lokasi, yaitu Kota Batam, Provinsi Kepulauan Riau dan Kabupaten Pangkajene dan Kepulauan, Provinsi Sulawesi Selatan. Meskipun upaya penanggulangan kemiskinan mencakup berbagai kegiatan, dalam tulisan ini pembahasan dibatasi pada kegiatan MPA, dengan fokus pada faktor-faktor yang berpengaruh terhadap keberhasilan dan kegagalan kegiatan tersebut. Data yang digunakan berupa data kualitatif yang diperoleh dari penelitian di kedua lokasi selama kurun waktu 2006 - 2011. Data diperoleh dari narasumber-narasumber yang berasal dari berbagai kalangan, antara lain penerima bantuan MPA dan pengelola kegiatan tersebut, menggunakan teknik wawancara mendalam dan FGD (focus group discussion). Pemilihan narasumber dilakukan secara purposive berdasarkan pertimbangan penguasaan terhadap data yang hendak dikumpulkan.

\section{PENDUDUK MISKIN DI SEKTOR PERTANIAN}

Data menunjukkan bahwa pada bulan Maret 2015 sekitar 28,59 juta penduduk Indonesia (11,22 persen) termasuk kategori miskin, yaitu mereka yang memiliki pengeluaran per kapita di bawah garis kemiskinan (http://bps.go.id/website/brs ind/brsInd-

20150915122517.pdf). Jika dibandingkan dengan 6 bulan sebelumnya (September 2014) ${ }^{5}$, jumlah ini bertambah sekitar 860.000 orang. Pada saat itu jumlah penduduk miskin adalah 27,73 juta orang $(10,95$ persen dari seluruh penduduk Indonesia. Di antara seluruh miskin, persentase yang tinggal di perdesaan lebih besar dibandingkan dengan di perkotaan, yaitu 14,21 persen dan 8,29 persen persen pada Maret 2015 secara berturut-turut.

Lebih besarnya proporsi penduduk miskin di wilayah perdesaan daripada di perkotaan merupakan fenomena yang telah lama terjadi. World Bank (2006)

\footnotetext{
5 Garis kemiskinan ditetapkan oleh pemerintah Indonesia pada tahun 2014 berdasarkan pendapatan per kapita per bulan sebesar Rp.312.328,-(http://www.indonesiainvestments.com/id/keuangan/angka-ekonomimakro/kemiskinan/item301).
} 
mengemukakan beberapa karakteristik penduduk miskin Indonesia, yaitu sekitar 65 persen tinggal di perdesaan, 55 persen di antaranya berpendidikan rendah (kurang dari pendidikan dasar), bahkan sekitar 16 persen buta huruf, dan sekitar 64 persen bekerja di sektor pertanian. Selain itu, mereka juga memiliki akses terhadap pemenuhan kebutuhan dasar yang terbatas, antara lain 73 persen tidak memiliki akses sanitasi yang layak, 50 persen tinggal di desa-desa tanpa pendidikan lanjutan (SLTP dan SLTA), 49 persen tanpa akses telepon, serta sekitar 47 persen melahirkan dibantu oleh bidan tidak terlatih. Semua kondisi tersebut mencerminkan kondisi kerentanan dari penduduk miskin.

Sektor pertanian yang merupakan lapangan pekerjaan sekitar 65 persen penduduk miskin Indonesia mencakup pertanian dalam arti luas. Ini antara lain termasuk perikanan (tangkap), mata pencaharian utama penduduk yang tinggal di pesisir dan pulaupulau kecil yang tersebar di berbagai wilayah Indonesia. Kemiskinan sangat melekat dengan nelayan. Meskipun Indonesia merupakan negara perairan dengan potensi berbagai jenis ikan melimpah, masih banyak nelayan, terutama yang berskala tradisional hidup dalam kondisi kemiskinan. Oleh karena itu, tidak berlebihan jika Dahuri (2012) mengatakan bahwa kata "nelayan" seolah-olah identik dengan kemiskinan.

Terdapat banyak faktor yang menyebabkan sebagian besar nelayan hidup dalam kemiskinan, mencakup faktor teknis, faktor kultural, dan faktor struktural (Dahuri, 2012). Semuanya bermuara pada pendapatan nelayan yang tidak menentu, antara lain karena stok sumber daya ikan yang menurun akibat pencemaran, kerusakan ekosistem laut sebab penangkapan ikan yang merusak, serta kondisi alam seperti perubahan iklim global. Selain itu, kondisi gelombang laut yang kuat pada musim-musim tertentu menyebabkan nelayan tradisonal tidak dapat menghasilkan pendapatan yang memadai dalam melaut. Masa ini dikenal sebagai masa paceklik yang memaksa nelayan untuk melakukan berbagai upaya guna mempertahankan kelangsungan hidup.

Fenomena kemiskinan nelayan ini sesungguhnya tidak hanya tipikal Indonesia, melainkan juga di belahan dunia lainnya. Dari kajian berbagai literatur yang dilakukan oleh Olale, dkk. (2010) diketahui bahwa di negara-negara berkembang masyarakat nelayan terkait erat dengan kemiskinan dan ada kecenderungan mengalami peningkatan. Di benua Afrika, khususnya, kondisi kemiskinan banyak ditemukan di wilayah pantai Kenya dan danau Victoria. Selanjutnya, Ifejika, dkk. (2013) mengemukakan bahwa di Nigeria, sekitar 69 persen penduduk miskin adalah mereka yang bekerja di sektor pertanian. Bahkan kelompok termiskin dari penduduk miskin tersebut adalah nelayan yang aktivitas ekonominya sangat tergantung pada kegiatan eksploitasi sumber daya laut. Kenyataan yang sama juga ditemukan di negara lain seperti Filipina. Tingkat kemiskinan penduduk yang tinggal di beberapa pantai di negara kepulauan tersebut mencapai sekitar 90 persen (Asian Development Bank, 1999).

\section{PENCIPTAAN MATA PENCAHARIAN ALTERNATIF (MPA) SEBAGAI SALAH SATU STRATEGI PENGURANGAN KEMISKINAN}

Bagi penduduk yang bermukim di pulau-pulau kecil dan pesisir, mata pencaharian di bidang perikanan tangkap merupakan sumber ekonomi rumah tangga yang paling utama. Meskipun demikian, kegiatan ekonomi di sektor ini tidak dapat menjamin ketahanan ekonomi rumah tangga secara berkelanjutan. Hal ini terutama dipengaruhi oleh kondisi rentannya sektor perikanan tangkap terhadap berbagai ancaman, seperti perubahan iklim, degradasi lingkungan, serta eksploitasi sumber daya perikanan yang berlebihan. Situasi ini umumnya diperparah dengan kondisi tingginya tekanan penduduk di tengah keterbatasan sumberdaya lahan di wilayah pesisir.

Agar para nelayan dapat mempertahankan penghasilan di tengah berbagai ancaman yang dialami sektor perikanan dan sekaligus mengurangi kemiskinan di antara mereka, penting dilakukan upaya untuk menciptakan mata pencaharian tambahan bagi kelompok penduduk ini, yang antara lain diperoleh melalui penciptaan mata pencaharian alternatif. Menurut Ireland (2004), mata pencaharian alternatif dapat diartikan sebagai mata pencaharian di luar kegiatan ekonomi tradisional atau kegiatan ekonomi yang telah umum dilakukan sebelumnya oleh penduduk di suatu wilayah. MPA dapat dipahami sebagai usaha untuk membuka pilihan pekerjaan bagi masyarakat agar mereka tidak hanya terbatas pada jenis pekerjaan tertentu. Kegiatan mata pencaharian alternatif dilakukan dengan diversifikasi pekerjaan yang sekaligus juga bertujuan untuk mengurangi risiko dan kerentanan terkait dengan kemiskinan (Brugere, dkk., 2008).

Beberapa penelitian yang telah dilakukan di negaranegara Afrika seperti Kenya dan Nigeria mendapatkan bahwa salah satu cara untuk mengurangi kemiskinan di kalangan nelayan adalah melalui diversifikasi pendapatan (Olale \& Henson, 2013; Tavida, dkk., 2011). Diversifikasi pendapatan dilakukan dengan beberapa cara, mulai dari mengganti pekerjaan sampai 
dengan melakukan pekerjaan-pekerjaan yang masih terkait dan saling melengkapi dengan pekerjaan sebelumnya (Brugere, dkk., 2008). Namun sayangnya, penelitian mengenai diversifikasi pekerjaan di kalangan nelayan masih terbatas. Selama ini penelitian mengenai isu tersebut masih cenderung dilakukan untuk masyarakat petani (Olale, dkk., 2010).

Kegiatan MPA yang pada gilirannya memberikan penghasilan tambahan tidak hanya diperlukan untuk memberikan jaminan ketahanan finansial bagi masyarakat di wilayah pesisir, melainkan juga dibutuhkan untuk menjaga keberlangsungan sumberdaya kelautan. Dalam konteks masyarakat nelayan, diversifikasi pekerjaan melalui penciptaan mata pencaharian alternatif juga bertujuan untuk mengurangi ketergantungan yang tinggi terhadap eksploitasi sumber daya laut (Brugere, dkk., 2008). Oleh karena itu, kegiatan MPA harus dipastikan tidak akan berdampak pada degradasi lingkungan di wilayah pesisir (Tobey, 2003). Lebih lanjut, dalam melaksanakan kegiatan MPA perlu pula dicermati kondisi sosial ekonomi, budaya, dan isu-isu lokal pada masyarakat setempat.

Selain dilakukan pada masa paceklik, kegiatankegiatan MPA/diversifikasi pekerjaan juga dapat dijalankan secara terus menerus untuk mengurangi eksploitasi berlebihan terhadap sumber daya laut. Eksploitasi sumber daya laut secara berlebihan, apalagi diikuti dengan penggunaan alat tangkap yang merusak telah menimbulkan dampak negatif bagi ekosistim perairan. Dahuri (2012) mengemukakan beberapa jenis kegiatan yang dapat digunakan untuk mengalihkan mata pencaharian nelayan tangkap antara lain budidaya, baik budidaya laut (marine culture), tambak, dan budidaya di perairan air tawar, industri pengolahan hasil perikanan, industri bioteknologi kelautan, dan industri serta jasa penunjang perikanan lainnya. Beberapa jenis kegiatan tersebut juga sudah dipraktekkan di beberapa negara, seperti Filipina, Madagaskar, dan Nigeria, termasuk juga untuk tujuan mengurangi kerusakan sumber daya alam (Asian Development Bank, 1999; Harris, 2007; Brugere, dkk., 2008; Ifejika, dkk., 2013).

Keberhasilan diversifikasi pekerjaan ditentukan oleh beberapa faktor. Dalam studinya di kalangan masyarakat nelayan di Kenya bagian barat, Olale dkk. (2010) menemukan bahwa faktor-faktor tersebut antara lain pendidikan, jenis pekerjaan yang terkait dengan kenelayanan (misalnya nelayan, pedagang ikan), keikutsertaan dalam organisasi kemasyarakatan, dan ketersediaan akses pendanaan untuk melaksanakan pekerjaan alternatif selain nelayan. Beberapa di antara faktor tersebut tidak hanya berpengaruh dalam upaya penciptaan pekerjaan alternatif di kalangan nelayan, akan tetapi juga di masyarakat petani. Winters, dkk. (2009) mengemukakan bahwa pendidikan memberikan kemudahan bagi seseorang untuk berpindah pekerjaan dari sektor pertanian ke pekerjaan-pekerjaan lain di luar sektor tersebut. Oleh karena itu, untuk mencapai keberhasikannya, para pengelola kegiatan penciptaan pekerjaan alternatif perlu mempertimbangkan berbagai faktor di atas.

\section{PELAKSANAAN KEGIATAN MATA PENCAHARIAN ALTERNATIF DI KOTA BATAM DAN KABUPATEN PANGKEP}

Penduduk di wilayah pesisir Kota Batam dan Kabupaten Pangkep memiliki ketergantungan yang besar terhadap sumber daya laut. Hal ini terlihat dari mata pencaharian mayoritas penduduk bersumber dari sektor perikanan tangkap (Noveria \& Aswatini 2007; Noveria, Harfina, \& Malamassam, 2011). Seperti telah dikemukakan sebelumnya, penghasilan yang diperoleh dari kegiatan perikanan tangkap sangat rentan terhadap perubahan kondisi cuaca, khususnya kondisi ekstrim yang cenderung terjadi sekitar satu dekade terakhir.

Berdasarkan hal tersebut terlihat bahwa situasi kerentanan ekonomi yang cukup tinggi dialami oleh penduduk di pulau-pulau kecil dan pesisir di kedua kabupaten yang dikaji dalam studi ini (Noveria \& Malamassam 2009; Romdiati \& Noveria, 2009; Noveria, Harfina, \& Malamassam, 2011). Perubahan gelombang laut yang cukup ekstrim sepanjang tahun berpengaruh pada kesulitan rumah tangga nelayan untuk memperoleh pendapatan yang stabil. Di Kabupaten Pangkep (Desa Mattiro Bombang dan Kelurahan Pundatta Baji), nelayan memperoleh pendapatan yang cukup tinggi hanya pada masa gelombang tenang dan pancaroba. Ketika masa gelombang laut kuat dan cuaca buruk, jumlah hari melaut para nelayan berkurang drastis sehingga mengakibatkan turunnya pendapatan nelayan. Kondisi sebaliknya terjadi pada nelayan di Pulau Abang dan Pulau Karas, Kecamatan Galang Baru, Kota Batam yang memperoleh pendapatan tertinggi pada masa gelombang kuat. Sementara itu, pada musim gelombang tenang dan pancaroba, hasil tangkapan mereka umumnya berkurang banyak sehingga berdampak pada penurunan pendapatan rumah tangga. Ketidakstabilan pendapatan rumah tangga para nelayan perikanan tangkap mengindikasikan pentingnya penciptaan mata pencaharian alternatif dalam rangka tetap menjaga ketahanan ekonomi rumah tangga sekaligus meningkatkan kesejahteraan masyarakat setempat. 
Kondisi di atas mendorong pentingnya usaha penciptaan MPA di wilayah pesisir di Kota Batam dan Kabupaten Pangkajene Kepulauan. Seperti yang dikemukakan Noveria \& Malamassam (2009), penciptaan dan pemberdayaan MPA diperlukan untuk membuka kesempatan bagi masyarakat nelayan untuk memperoleh tambahan penghasilan rumah tangga. Tidak seperti aktivitas perikanan tangkap, aktivitas MPA diharapkan dapat memberikan insentif ekonomi bagi rumah tangga nelayan tanpa terpengaruh perubahan cuaca ataupun gelombang laut.

Berbagai kegiatan MPA telah diinisiasi, baik oleh institusi pemerintah, organisasi non-pemerintah maupun pihak masyarakat secara mandiri, di kedua lokasi penelitian ini. Umumnya, inisiatif pelaksanaan kegiatan MPA tersebut diwujudkan dalam bentuk pemberian bantuan modal usaha untuk berbagai kegiatan ekonomi produktif, serta pelatihan dan bimbingan teknis untuk pelaksanaan kegiatan tersebut. Pelatihan dilaksanakan pada awal pelaksanaan kegiatan, sedangkan bimbingan teknis diberikan selama kegiatan MPA berlangsung. Dalam skema Coremap, bantuan modal untuk kelompok kegiatan MPA disalurkan melalui Dinas Kelautan dan Perikanan kabupaten yang bekerjasama dengan pihak lembaga swadaya masyarakat (LSM) atau organisasi non-pemerintah untuk pelatihan dan bimbingan teknis.

Kegiatan MPA dalam skema Coremap diarahkan untuk usaha ekonomi produktif, baik yang berkaitan dengan pengelolaan sumberdaya kelautan maupun non kelautan. Sesuai dengan ketentuan yang telah ditetapkan, kegiatan MPA yang dapat dibantu Coremap adalah usaha produktif dengan bahan baku sumberdaya alam yang tersedia di lingkungan setempat. Secara umum, kegiatan dapat dibagi menjadi dua kategori yaitu (1) usaha ekonomi produktif yang berbasis kegiatan di wilayah perairan atau lautan; dan (2) usaha ekonomi produktif yang berbasis kegiatan di wilayah daratan. Untuk program MPA yang terkait dengan pengelolaan sumberdaya laut, usaha ekonomi produktif yang dilakukan adalah budidaya perikanan (laut) dengan menggunakan keramba jaring apung (KJA) dan keramba jaring tangkap (KJT). Sementara itu, program MPA yang berbasis kegiatan di darat meliputi usaha ekonomi produktif di sektor pertanian, perdagangan, industri rumah tangga dan pariwisata.

Kegiatan MPA yang diinisiasi oleh Coremap disyaratkan untuk dilakukan secara berkelompok, baik oleh laki-laki maupun perempuan. Jumlah anggota kelompok bervariasi, antara 5-18 orang (Romdiati \& Noveria, 2007). Pembentukan kelompok difasilitasi oleh petugas lapangan Coremap, antara lain didasarkan pada kesamaan mata pencaharian. Karena mayoritas laki-laki bekerja sebagai nelayan, kelompok laki-laki terdiri dari para nelayan dan kegiatan MPA yang dilakukan adalah budidaya perikanan (laut) dengan keramba jaring tancap (KJT) dan keramba jaring apung (KJA). Jenis sumber daya laut yang dibudidayakan dalam KJT dan KJA adalah ikan kerapu, khususnya kerapu macan. Sementara itu, perempuan terlibat dalam kegiatan MPA yang berorientasi darat, misalnya pembuatan kerupuk ikan, kue-kue basah, perdagangan kelontong, dan peternakan ayam dengan skala rumah tangga.

Dukungan terhadap penciptaan MPA oleh Coremap diwujudkan dalam berbagai bentuk bantuan. Salah satu di antaranya adalah modal usaha, yang diberikan dalam jumlah yang sesuai dengan kebutuhan kelompok, melalui penilaian terhadap proposal yang diajukan oleh masing-masing kelompok. Untuk kegiatan budidaya perikanan di Kota Batam, misalnya, bantuan modal usaha mencakup penyediaan bibit dan alat serta pemberian uang pakan dan biaya operasional sampai masa panen. Secara keseluruhan, jumlah dana berkisar sekitar Rp. 10.000,000,- sampai dengan Rp. 15.000.000,- (Romdiati dan Noveria, 2007). Kelompok-kelompok MPA di luar kegiatan perikanan memperoleh dana bantuan dengan jumlah yang juga bervariasi, misalnya antara Rp. 500.000,- sampai dengan Rp. 2.000.000,- di Kabupaten Pangkep (Noveria, Harfina, \& Malamassam, 2011; Noveria, Harfina, Malamassan \& Hidayati, 2011) dan mencapai sekitar Rp. 5.000.000,- di Kota Batam (Romdiati dan Noveria, 2007). Bantuan modal yang diberikan bersifat dana bergulir. Oleh karena itu, semua kelompok harus mengembalikannya dengan cara mencicil kepada pekerja lapangan Coremap, sesuai dengan ketentuan yang telah disepakati. Dana cicilan dari kelompok-kelompok yang ada kemudian diberikan kepada kelompok lain yang belum memperoleh bantuan.

Selain modal usaha, bantuan yang diberikan berupa pendampingan oleh tenaga ahli. Pendamping bertugas untuk memberikan bimbingan, baik dalam hal peningkatan kapasitas kelompok masyarakat, peningkatan pengetahuan teknis dalam pelaksanaan kegiatan MPA, serta keterampilan pembukuan keuangan kegiatan MPA. Adakalanya kelompokkelompok yang sudah panen juga mendapat bantuan dalam penjualan hasilnya.

Terdapat perbedaan karakteristik dan mekanisme pelaksanaan kegiatan pada kelompok-kelompok MPA di Kota Batam dan Kabupaten Pangkep. Di Kota Batam, semua anggota dalam suatu kelompok mengerjakan satu jenis pekerjaan secara kolektif yang merupakan kegiatan kelompok, misalnya budidaya 
ikan kerapu dan membuat kerupuk ikan atau telur asin. Sebaliknya, di Kabupaten Pangkep anggota-anggota kelompok mengerjakan kegiatan ekonomi masingmasing karena dana bantuan modal usaha diberikan kepada masing-masing individu. Artinya, kelompok hanya menjadi wadah untuk penyaluran dana, sementara itu, tidak ada pekerjaan kolektif yang dilakukan oleh semua anggota sebagai suatu kelompok.

Selain Coremap, terdapat pula beberapa kegiatan penciptaan MPA yang dilaksanakan oleh instansiinstansi pemerintahan lainnya melalui berbagai program yang antara lain bertujuan untuk menanggulangi kemiskinan. Salah satunya adalah, bantuan pemerintah pusat melalui Kementerian Koordinator Kesejahteraan Rakyat (Kemenkokesra) melalui program PNPM Mandiri. Melalui salah satu kegiatannya yaitu SPP (Simpan Pinjam Perempuan), program ini memberikan bantuan dana bergulir khusus untuk perempuan yang dapat digunakan sebagai modal usaha ekonomi produktif. Khusus di wilayah pulaupulau kecil dan pesisir, dana bantuan dari SPP ini dapat dimanfaatkan untuk kegiatan MPA rumah tangga nelayan, meskipun secara langsung diberikan kepada kelompok perempuan. Selain itu, terdapat bantuan dari Kementerian Sosial melalui program Koperasi Syariah yang juga memberikan bantuan pinjaman modal untuk usaha ekonomi produktif. Tidak hanya pemerintah pusat, pihak pemerintah daerah pun melakukan inisiasi penciptaan mata pencaharian alternatif. Sebagai contoh, di Kabupaten Pangkep, pemerintah daerah melalui Dinas Kelautan dan Perikanan, yang juga bekerjasama dengan pihak perguruan tinggi negeri di Kota Makassar, memberikan bantuan modal, alat dan bimbingan untuk budidaya rumput laut dan budidaya ikan hias. Skema bantuan ini utamanya diarahkan untuk menciptakan sumber pendapatan ekonomi yang tidak merusak sumberdaya laut.

\section{KEGIATAN MATA PENCAHARIAN ALTERNATIF: FAKTOR PENDUKUNG DAN PENGHAMBAT}

Seperti telah dikemukakan sebelumnya, programprogram penanggulangan kemiskinan memiliki kegiatan yang secara langsung maupun tidak langsung bertujuan untuk meningkatkan kondisi ekonomi masyarakat. Kegiatan yang secara langsung berkaitan dengan peningkatan pendapatan adalah usaha ekonomi produktif. Sub bagian ini mendeskripsikan faktorfaktor pendukung dan penghambat dalam pelaksanaan kegiatan MPA.

\section{Faktor Pendukung Pelaksanaan Kegiatan Mata Pencaharian Alternatif}

Menurut Tobey (2004), terdapat beberapa hal yang mendukung suksesnya penciptaan dan pemberdayaan kegiatan MPA di wilayah pesisir dan pulau-pulau kecil. Hal pertama adalah adanya bimbingan teknis dan manajemen, baik dalam bentuk pelatihan maupun pendampingan lapangan. Bimbingan ini sebaiknya tidak hanya diberikan pada awal program bantuan saja, namun berlangsung secara berkelanjutan. Hal lain yang perlu diperhatikan adalah kegiatan MPA harus dapat memberikan insentif ekonomi yang sama atau bahkan lebih baik jika dibandingkan dengan kegiatan perikanan tangkap. Kedua, pemahaman yang menyeluruh terhadap beberapa komponen penting dalam penciptaan usaha ekonomi produktif juga diperlukan dalam mendukung suksesnya pelaksanaan kegiatan MPA. Komponen-komponen tersebut antara lain adalah pasar hasil produksi, pengetahuan mengenai risiko usaha, akses terhadap kredit mikro, aktivitas yang menjaga kelestarian lingkungan, serta pemahaman mengenai heterogenitas kelompok masyarakat di suatu wilayah.

Salah satu kunci sukses seperti yang dikemukakan di atas dilaksanakan dalam kegiatan MPA Coremap. Seperti telah dikemukakan pada bagian sebelumnya, bimbingan teknis dan pendampingan diberikan kepada kelompok-kelopok penerima bantuan modal untuk kegiatan MPA. Untuk kelompok budidaya ikan dengan KJT dan KJA, bimbingan teknis diberikan mulai dari penempatan bibit sampai dengan pemanenan ikan.

Faktor pendukung lain untuk penciptaan MPA di kedua wilayah pesisir adalah ketersediaan sumberdaya manusia yang akan melaksanakan kegiatan pekerjaan alternatif tersebut. Proporsi penduduk usia produktif, baik di Kota Batam dan Kabupaten Pangkep, tergolong tinggi (Noveria \& Malamassam 2009; Noveria, Harfina, \& Malamassam, 2011). Kondisi ini mencerminkan ketersediaan angkatan kerja yang cukup besar sebagai modal penciptaan lapangan kerja alternatif di kedua wilayah ini. Meskipun secara umum tingkat pendidikan penduduk di wilayah penelitian tergolong rendah, mayoritas penduduk setempat memiliki pengetahuan yang memadai mengenai pentingnya upaya pelestarian sumber daya laut. Pemahaman mengenai hal ini menjadi dasar penting dalam usaha mengadvokasi masyarakat di wilayah pesisir mengenai pentingnya penciptaan kegiatan MPA.

Selanjutnya, ketersediaan sarana prasarana yang dapat mendukung pemasaran produksi kelompok kegiatan MPA di kedua wilayah pesisir ini menjadi faktor 
pendukung lainnya. Meskipun terletak cukup jauh dari pusat kota, ketersediaan sarana transportasi publik cukup memadai di kedua lokasi penelitian. Hal ini memudahkan untuk membawa produksi ke pasar (http://www.dkpkepri.info) atau sebaliknya, pihak pembeli datang ke lokasi yang menghasilkan produk. Selain itu, penduduk memiliki akses yang cukup baik terhadap sarana informasi dan komunikasi. Hal ini ditunjukkan dengan akses terhadap siaran televisi nasional serta jaringan telepon seluler yang tersedia di kedua wilayah pesisir ini. Ketersediaan jaringan telepon seluler memudahkan penduduk untuk mengetahui ketersediaan pasar serta harga komoditas yang mereka hasilkan.

Pangsa pasar yang besar bagi produksi budidaya perikanan melalui KJT dan KJA menjadi faktor pendukung yang juga tidak kalah pentingnya. Jenis ikan kerapu, khususnya kerapu macan yang dibudidayakan oleh kelompok KJT dan KJA di lokasi Coremap di Kota Batam memiliki prospek yang bagus di pasar luar negeri seperti Singapura dan Hongkong (http://skpd.batamkota.go.id/kp2k). Hasil panen biasanya langsung dijual kepada pedagang penampung untuk selanjutnya dijual ke pasar dalam negeri maupun luar negeri (http://www.dkpkepri.info). Harga ikan kerapu yang tinggi di Singapura menyebabkan kegiatan budidaya jenis ikan tersebut sangat diminati oleh penduduk di Kepulauan Riau, termasuk di Batam (Zakaria, tanpa tahun).

Selain kegiatan kenelayanan, kegiatan MPA yang berpotensi dikembangkan di wilayah pesisir adalah sektor industri rumah tangga, yaitu pengolahan hasil perikanan tangkap. Rumah tangga nelayan umumnya telah mengolah sebagian kecil hasil tangkapannya untuk menjadi kerupuk ikan, sambal ikan, ikan asin, ataupun ikan asap. Hasil produksi industri rumah tangga ini umumnya didistribusikan secara terbatas. Kemampuan pengolahan komoditas perikanan, walaupun masih terbatas, dapat menjadi modal dasar dalam pengembangkan sumber ekonomi alternatif.

Untuk pengembangan MPA di bidang pertanian, khususnya di Kota Batam, potensi pengolahan sumberdaya pertanian masih cukup besar. Hal ini dipengaruhi oleh kondisi ketersediaan lahan pertanian yang masih cukup luas di wilayah ini. Pulau Abang kecil yang menjadi salah satu lokasi Coremap, misalnya, memiliki 40 persen lahan dengan topografi datar-berombak dari total luas sekitar 6,003 km2 (regional.coremap.or.id). Lahan dengan kondisi topografi tersebut sesungguhnya dapat dimanfaatkan untuk kegiatan pertanian, misalnya menanam sayursayuran serta buah-buahan. Namun dalam kenyataannya, lahan potensial tersebut diterlantarkan oleh masyarakat. Situasi ini sangat berbeda dengan kondisi di Desa Mattiro Bombang di Kabupaten Pangkep yang tidak lagi memiliki lahan pertanian yang memadai untuk dikelola karena hampir semua wilayah pulau sudah dimanfaatkan untuk pemukiman penduduk.

\section{Aspek Sosial Budaya: Faktor penghambat kegiatan MPA}

Meskipun telah memperlihatkan hasil yang positif, program MPA tidak terlepas dari hambatan. Berbagai hambatan muncul, baik akibat faktor alam, kendala teknis yang berpengaruh terhadap aktifitas ekonomi maupun karena faktor manusia yang menerima bantuan. Kendala teknis bisa diatasi melalui pemberian pendampingan/bimbingan teknis dalam menjalankan aktifitas ekonomi dan kendala alam diatasi dengan melakukan berbagai penyesuaian terhadap kondisi alam. Selanjutnya, hambatan yang berasal dari faktor manusia, khususnya karena sikap dan kebiasaan serta pandangan terhadap kegiatan MPA, hanya dapat diatasi melalui perubahan sikap, kebiasaan, dan pandangan mereka. Upaya ini sulit dilakukan dalam waktu singkat. Diperlukan waktu yang lama serta pendekatan khusus agar dapat merubah sikap, kebiasaan, dan pandangan yang sudah lama dilakukan dan dianut. Kendala yang muncul akibat faktor manusia, terutama sikap dan kebiasaan menjadi fokus bahasan pada subbagian ini.

Berkaitan dengan faktor-faktor yang menghambat pelaksanaan kegiatan MPA, hasil penelitian di kedua lokasi memperlihatkan beberapa kecenderungan yang sama. Salah satunya adalah kebiasaan dalam melakukan aktifitas ekonomi. Masyarakat di kedua lokasi kebanyakan adalah nelayan yang terbiasa bekerja sendiri atau bersama-sama dengan satu atau dua orang yang pada umumnya adalah anggota rumah tangga mereka. Bekerja dalam kelompok besar, misalnya 10 orang yang tergabung dalam kelompok KJA dan usaha industri rumah tangga merupakan hal yang sangat jarang atau bahkan tidak pernah dilakukan. Akibatnya, aktifitas ekonomi yang dilakukan secara bersama-sama dalam suatu kelompok sulit dilaksanakan.

Berdasarkan wawancara dengan beberapa narasumber di lokasi penelitian diketahui bahwa kerja kelompok hanya terlaksana pada awal kegiatan, misalnya saat membuat dan memasang karamba. Setelah itu, hanya satu atau dua orang yang ikut bekerja sampai panen. Bahkan, pada salah satu kelompok KJA di Kelurahan Pulau Abang (Kota Batam), hanya ketua kelompok yang terus bekerja dan terpaksa membayar orang lain yang bukan anggota kelompok untuk membantu, 
misalnya memberi makan ikan yang dibesarkan serta membersihkan karamba. Hal ini dikemukakan oleh seorang narasumber (bapak $\mathrm{S}$, ketua salah satu kelompok KJA di Kelurahan Pulau Abang) seperti kutipan berikut,

\begin{abstract}
Selama ini cuma Bapak sendiri yang kerja. Waktu dulu pasang keramba memang kita bekerja sama-sama satu kelompok, tapi lamalama mulai ada yang diam-diam tidak datang kerja. Ada juga yang bilang ndak jadi anggota kelompok lagi. Akhirnya Bapak suruh orang untuk urus, kasih makan ikan dan bersih-bersih karamba. Orang itu dikasih upah.
\end{abstract}

Kenyataan di atas tidak sejalan dengan prinsip kerja yang telah disepakati sejak awal, yaitu seluruh anggota kelompok KJA bekerja bersama-sama sampai panen. Hasil panen kemudian dibagi bersama-sama, setelah menyisihkan jumlah yang akan digunakan untuk modal usaha selanjutnya dan yang harus dikembalikan ke penyelenggara Coremap. ${ }^{6}$ Namun, keberhasilan yang dicapai oleh salah satu kelompok di atas kemudian menumbuhkan motivasi di kalangan nelayan lainnya untuk melakukan kegiatan yang sama. Setelah itu, ada kelompok yang sebelumnya tidak melanjutkan aktifitas, akan melaksanakan kembali kegiatan mereka, sebagaimana dikemukakan oleh narasumber yang sama.

\begin{abstract}
... setelah Bapak panen terus orang-orang liat..ooh bisa juga dapat uang ya. Akhirnya mereka jadi bersemangat untuk kerja karamba lagi. Ini ada yang bilang mau usaha kelompok lagi. Jadi mereka harus liat bukti dulu, baru mau bekerja...
\end{abstract}

Kondisi yang sama juga dihadapi oleh kelompok perempuan pembuat kerupuk ikan dan pembuat telur asin. Keterlibatan anggota sangat tidak menentu dan dipengaruhi oleh aktifitas dan kepentingan mereka di rumah masing-masing. Anggota kelompok biasanya meninggalkan pekerjaan di kelompok jika mereka sedang sibuk dengan urusan rumah tangga. Pekerjaan kelompok selanjutnya menjadi tanggung jawab ketua kelompok, sehingga tidak terelakkan menimbulkan kesan bahwa usaha ekonomi yang dilakukan oleh ketua kelompok adalah kegiatan individu.

\footnotetext{
${ }^{6}$ Bantuan modal usaha untuk kegiatan MPA diberlakukan sebagai "hutang" dan harus dikembalikan kepada penyelenggara Coremap di tingkat desa/kelurahan. Dana pengembalian tersebut kemudian digulirkan kepada kelompok lainnya. Jika usaha KJA dan pembayaran "hutang" berjalan, maka akan makin banyak kelompok dalam masyarakat yang bisa menerima manfaat dari kegiatan MPA. Hal ini pada gilirannya menciptakan sumber mata pencaharian baru bagi masyarakat, di samping juga mengurangi ketergantungan terhadap sumber daya laut.
}

Masih terkait dengan pelaksanaan kegiatan ekonomi, salah satu penghambat dalam pelaksanaan MPA adalah lamanya waktu tunggu untuk mendapatkan hasil pekerjaan. Tidak seperti kegiatan melaut yang bisa memperoleh hasil secara cepat, pekerjaanpekerjaan yang termasuk kegiaan MPA memerlukan waktu tertentu untuk memperoleh hasil. Sebagai contoh, ikan yang dibesarkan di KJA pada umumnya dipanen 9 bulan setelah bibit dimasukkan dalam karamba. Hal yang sama juga terjadi di kalangan mereka yang melakukan kegiatan MPA di bidang pertanian, seperti yang menaman sayuran. Masa panen sayuran sekitar 3 bulan juga dirasakan lama oleh keluarga nelayan karena mereka terbiasa memperoleh uang tunai secara cepat, yaitu langsung setelah pulang melaut. Pada umumnya mereka berkeberatan dengan cara kerja seperti budidaya ikan dengan KJA serta bertanam sayuran ini. Akibatnya, mereka tetap menjadikan kegiatan menangkap ikan di laut sebagai pekerjaan utama dan meninggalkan kegiatan MPA.

Secara konsep, kegiatan MPA yang diperkenalkan Coremap (serta program-program penanggulanan kemiskinan lainnya di daerah kepulauan dan pesisir) bertujuan untuk mengurangi tekanan terhadap sumber daya laut. Kegiatan tersebut sesungguhnya tidak dimaksudkan untuk menggantikan atau menghentikan sama sekali kegiatan melaut di kalangan nelayan. Dengan MPA, aktifitas melaut diharapkan dapat dikurangi, yang pada gilirannya berpengaruh positif terhadap kelangsungan hidup sumber daya laut. Akan tetapi, keinginan kuat untuk memperoleh uang secara cepat menyebabkan para nelayan menerima bantuan kegiatan MPA tidak mengurangi intensitas pekerjaan menangkap ikan di laut. Oleh karena itu, untuk mencapai tujuan dari kegiatan MPA, diperlukan waktu yang lama agar perilaku dan pandangan masyarakat dalam memperoleh penghasilan bisa berubah.

Satu hal lain yang tidak kalah pentingnya dalam menghambat pelaksanaan kegiatan MPA adalah pandangan/penerimaan masyarakat terhadap bantuan yang diberikan. Di kalangan masyarakat di lokasi penelitian di Pangkep, dikenal istilah "uang mati" untuk bantuan dana usaha ekonomi produktif yang dikucurkan melalui berbagai program penanggulangan kemiskinan (Noveria, Harfina, \& Malamassam, 2011). Artinya, uang yang telah diterima merupakan pemberian dari pemerintah atau penyelenggara kegiatan tanpa harus dikembalikan lagi. Padahal, menurut konsepnya uang yang diterima harus diperlakukan sebagai "hutang" yang harus dikembalikan untuk selanjutnya bisa pula dimanfaatkan bagi penerima bantuan yang lain. Dengan demikian, semakin banyak anggota 
masyarakat yang mendapatkan bantuan untuk modal kegiatan ekonomi.

Anggapan bahwa dana bantuan untuk kegiatan MPA adalah "uang mati" juga menyebabkan sebagian penerimanya memanfaatkan bantuan tersebut bukan untuk kegiatan ekonomi produktif. Hasil penelitian di Kabupaten Pangkajene dan Kepulauan bahkan menemukan bahwa ada penerima yang menggunakan dana bantuan untuk memenuhi kebutuhan sehari-hari (Noveria, Harfina, \& Malamassam, 2011). Akibatnya, kegiatan penciptaan MPA tidak memunculkan mata pencaharian alternatif bagi penerimanya. Khusus untuk kegiatan MPA Coremap, kenyataan di atas diperburuk dengan tidak adanya sanksi yang tegas bagi mereka yang tidak mengembalikan dana bantuan. Hal ini memberikan pengaruh negatif bagi mereka yang telah mengembalikan pinjaman. Dengan pertimbangan bahwa tidak ada sanksi bagi mereka yang tidak mengembalikan pinjamannya, sebagian penerima bantuan yang terbiasa mengembalikan pinjaman secara teratur juga menghentikan pengembaliannya (wawancara dengan salah seorang ibu, pengelola kegiatan MPA di Pangkep). Konsekuensinya, dana MPA tidak bisa digulirkan kepada kelompok yang lain.

Berbeda dengan Coremap, kegiatan simpan pinjam untuk usaha ekonomi yang dilakukan oleh PNPM Mandiri berjalan dengan lancar. Para penerima bantuan mengembalikan pinjaman dengan teratur, terutama karena program ini memberikan sanksi yang tegas bagi daerah-daerah yang tidak lancar pengembalian dana simpan pinjamnya. ${ }^{7}$ Dengan semikian, tidak mengherankan jika kegiatan SPP dari PNPM Mandiri bisa bertahan dalam waktu yang lebih lama.

\section{KESIMPULAN}

Upaya-upaya untuk menanggulangi kemiskinan telah menjadi perhatian pemerintah sejak lama, terbukti dari banyaknya program sejenis yang telah dilakukan. Beberapa di antara kegiatan yang dilaksanakan dalam program penanggulangan kemiskinan menunjukkan keberhasilan, misalnya dari peningkatan pendapatan penduduk yang menjadi target program. Namun, ada pula yang tidak berhasil mencapai tujuannya, misalnya kegiatan MPA yang pada umumnya menumbuhkan

\footnotetext{
${ }^{7}$ Daerah-daerah yang memiliki tunggakan cicilan dana SPP diberi sanksi berupa tidak dicairkannya dana untuk pembangunan infrastruktur pada tahun berikutnya. Aturan ini menjadi pendorong utama bagi pengembalian cicilan SPP.
}

usaha-usaha ekonomi produktif yang berbasis kelompok.

Dari bahasan di atas dapat disimpulkan bahwa terdapat berbagai faktor (pendukung dan penghambat) yang berpengaruh terhadap keberhasilan kegiatan MPA di lokasi penelitian. Salah satu faktor penghambat yang memerlukan waktu relatif lama untuk mengatasinya adalah yang berkaitan dengan nilai-nilai dan kebiasaan masyarakat dalam melakukan kegiatan ekonomi. Oleh karena itu, pendekatan sosial budaya menjadi penting dilakukan sebelum kegiatan MPA diluncurkan di suatu masyarakat. Hal ini antara lain dilakukan untuk merubah cara pandang masyarakat mengenai kegiatankegiatan yang dapat menghasilkan pendapatan rumah tangga. Masyarakat perlu diberi pemahaman bahwa usaha ekonomi tidak hanya dilakukan secara individu, melainkan juga bisa secara berkelompok.

Kegiatan penciptaan MPA sesungguhnya tidak hanya berupa pemberian bantuan modal usaha serta bimbingan teknis semata. Perlu pula upaya untuk merubah kebiasaan dan pandangan masyarakat terhadap sistim kerja yang hendak diperkenalkan. Oleh karenanya, kegiatan MPA tidak semata-mata menciptakan usaha ekonomi baru, namun juga memerlukan transformasi perilaku ekonomi masyarakat setempat. Pada kasus di kedua lokasi penelitian, membiasakan bekerja dalam kelompok dan memperoleh hasil kerja setelah menunggu selama waktu tertentu merupakan perubahan sosial yang diperlukan agar kegiatan MPA mencapai hasil yang optimal.

Berdasarkan kenyataan di atas, hal utama yang perlu disadari sebelum melakukan inisiasi kegiatan MPA adalah pentingnya pemahaman yang menyeluruh mengenai kondisi sosial ekonomi dan budaya masyarakat di wilayah pesisir. Para pengelola program perlu memahami kondisi sosial, termasuk kebiasaan dan pandangan masyarakat yang berkaitan dengan kegiatan-kegiatan yang akan dilaksanakan dalam penciptaan MPA. Dengan pemahaman mengenai kondisi sosial budaya masyarakat yang menjadi kelompok target, para pengelola dapat merencanakan berbagai upaya untuk mendukung keberhasilan program.

Upaya-upaya tersebut meliputi berbagai bentuk aktifitas. Pada awalnya adalah sosialisasi untuk memberikan pemahaman mengenai manfaat kegiatan ekonomi yang dilakukan secara berkelompok. Kegiatan ini selanjutnya diikuti dengan pelaksanaan kegiatan percontohan untuk bekerja dalam kelompok. Untuk itu, sebelum program dilaksanakan, perlu dibentuk (satu atau dua) kelompok contoh dengan 
mekanisme kerja sesuai dengan yang direncanakan dalam program. Pelaksanaan kegiatan kelompok contoh tersebut dimonitor dengan cermat, paling sedikit selama masa satu siklus produksi. Keterlibatan pemimpin masyarakat, formal maupun informal dalam pemantauan kegiatan kelompok contoh sangat diperlukan. Keberhasilan kelompok contoh menjadi bukti nyata bahwa kegiatan ekonomi dapat dilakukan dengan mekanisme kerja kelompok. Dengan demikian, diharapkan masyarakat dapat mengubah cara kerja yang selama ini mereka praktekkan dalam kegiatan ekonomi.

\section{DAFTAR PUSTAKA}

Bappenas. 1994. Kaji Tindak Program IDT 1994-1997. Jakarta: Bappenas.

Brugere, C., Holvet, K, \& Allison, E. 2008. Livelihood Diversification in Coastal and Inland Fishing Communities: Misconceptions, Evidence and Implications for Fiseheries Management. Working Paper, Sustainable Fisheries Livelihood Programme (SFLP). Rome, FAO/DFID.

Dahuri, Rokhmin. 2012. Akar Masalah Kemiskinan Nelayan dan Solusinya.

http://rokhmindahuri.info/2012/10/10/akarmasalah-kemiskinan-nelayan-dan-solusinya/. diunduh tanggal 10 Oktober 2015.

Harris, Alasdair. 2007. "To Live with the Sea" Development of the Velondriake Community-Managed Protected Area Network, Southwest Madagaskar. Madagaekar Conservation \& Development, Volume 2, Issue 2, hal. 43-49.

http://skpd.batamkota.go.id/kp2k/2014/10/08/info-tanjungriau-panen-kerapu/. Info; Tanjung Riau Panen Kerapu. diunduh tanggal 10 November 2015.

http://www.adb.org/sites/default/files/evaluationdocument/35266/files/17152-01-phi-ppar.pdf. Program Performance Audit Report on the Fisheries Sector Program in the Philippines. diunduh tanggal 11 November 2015.

http://www.dkpkepri.info. Budidaya Perikanan Kota Batam Budidaya Laut. diunduh tanggal 10 November 2015.

http://www.indonesia-investments.com/id/keuangan/angkaekonomi-makro/kemiskinan/item301. Kemiskinan di Indonesia. diunduh tanggal 11 November 2015.

http://www.pnpmperdesaan.or.id/?page=halaman\&story $\mathrm{id}=1$. diunduh tanggal 17 November 2014.

http://www.pnpmperdesaan.or.id $/$ ?page $=$ news $\&$ topic $=$ Pembangunan \&id=321. Bangun Jembatan, Menguak Keterisolasian. diunduh tanggal 17 November 2014. http://www.pnas.org/content/110/6/2076.full.pdf. Income diversification and risk for fishermen Stephen Kasperskia and Daniel S. Holland. diunduh tanggal 10 November 2015.

http://regional.coremap.or.id/downloads/KONDISI_GEOG RAFIS.pdf. Kondisi Geografis. diunduh tanggal 17 November 2015.

Ifejika, P.I, E.N. Belonwu, Y.Y. Malogwi, A.O. Odunuga, dan A.A. Mbah. 2013. "Emerging Income Generating Activities of Fisherfolk in Riverine Communities of Niger State, Nigeria". Journal of Fisheries and Aquatic Science, 2013/DOI:10.3923/jfes.2013.

Ireland, C. 2004. Alternative sustainable livelihoods for coastal communities: A review of experience and experience and guide to best practice. Somerset: theIDLgroup.

Noveria M. \& Aswatini. 2007. Kondisi sosial ekonomi masyarakat di lokasi COREMAP II: Kelurahan Karas Kota Batam. Jakarta: CRITC - LIPI.

Noveria M. \& Malamassam, M.A., 2009. Perkembangan pendapatan masyarakat di lokasi COREMAP II: Pulau Abang Kota Batam. Jakarta: Pusat Penelitian Kependudukan LIPI \& COREMAP.

Noveria M., Harfina, D. \& Malamassam, M.A., 2011. Pelestarian terumbu karang berbasis masyarakat: Suatu upaya peningkatan kesejahteraan masyarakat di Kabupaten Pangkajene Kepulauan. Jakarta: PT. Leuser Cita Pustaka \& COREMAPLIPI.

Noveria, M., Harfina, D, Malamassam, M.A. \& Hidayati, I. 2011. Program Rehabilitasi dan Pengelolaan Terumbu Karang di Kabupaten Pangkajene dan Kepulauan. Dampak Sosial Ekonomi Terhadap Masyarakat. Jakarta: PT Leuser Cita Pusaka \& COREMAP-LIPI.

Olale, Edward, Spencer Henson dan John Cranfield. 2010. "Determinants of Income Diversification among Fishing Communities in Western Kenya". Selected Paper prepared for presentation at the Agricultural \& Applied Economics Association 2010 AAEA, CAES, \& WAEA Joint Annual Meeting, Denver, Colorado, July 25-27, 2010. http://ageconsearch.umn.edu/bitstream/61259/2/Det erminants\%20of\%20ID\%20paper\%20-AAEA.pdf. diunduh tanggal 10 November 2015.

Olale, Edward \& Henson, Spencer. 2013. "The impact of income diversification among fishing communities in Western Kenya". Food Policy, 43, hal. 90-99.

Partinah, Tri Lisiani, Dora Marinova, \& Laura Stocker. 2011. "Empowering Women Through Income Generating Projects: Evidence from Indonesia". Paper dopresentasikan pada International Community Development Conference, Rotorua, New Zealand, April 2011. 
Project Appraisal Document. COREMAP II 2005.

Romdiati, H. \& Noveria, M. 2007. Kondisi Sosial Ekonomi Masyarakat di Lokasi Coremap II Desa Pulau Abang, Kota Batam. Hasil BME. Jakarta: CRITCLIPI.

Tavida, A.A., Adebayo. A.A., Galtima, M., Raji, A., Jimme, M. \& John, C.T. 2011. "Livelihood Strategies and Rural Income: The Case of Fishing Communities in Kainji Lake Basin Nigeria". Agricultural Journal, Volume 5, Issue 5, hal. 259-263.

Tobey, J. 2003. Coastal management and poverty alleviation, dalam S.B. Olsen (ed). Crafting coastal governance in a changing world. Coastal Management Report No. 2241. Rhode Island: Coastal Resource Management Program.

United Nations. 2015. Global Sustainable Development Reports. $2015 \quad$ Edition. https://sustainabledevelopment.un.org/globalsdrepo $\underline{\mathrm{rt} / 2015}$. diunduh tanggal 20 Agustus 2015.
Winters, Paul dkk,. 2009. "Asstes, Activities and Rural Income Generation: Evidence from a Multicountry Analysis". World Development. Vol. 37, No. 9, hal. 1435-1452.

World Bank. 2006. Making the New Indonesia Work for the Poor. Jakarta: the World Bank Office.

www.bps.go.id. Jumlah Penduduk Miskin, Presentase Penduduk Miskin, dan Garis Kemiskinan, 19702013. diunduh tanggal 17 November 2015.

Zakaria, Buchari. Tanpa tahun. WBL/85/WP - 17 Budidaya Laut dan Kemungkinan Pengembangannya di Propinsi Riau. http://www.fao.org/docrep/field/003/ab882e/AB88 2E17.htm. diunduh tanggal 10 November 2015. 